\title{
Tumefactive Multiple Sclerosis Mimicking Neoplasm
}

\author{
Liene Elsone*, Ardis Platkajis*, Guntis Karelis*, Sarmite Dzelzite*, Maira Murzina** \\ *Riga Stradins University, Latvia \\ **Latvian Multiple Sclerosis Centre, Riga, Latvia.
}

Summary. Acute demyelination may present as a rapidly expanding space-occupying or tumefactive lesion (TDL). Tumefactive demyelinating lesions are misdiagnosed quite frequently and can result in unnecessary and potentially harmful surgical resection, radiation or toxic chemotherapeutic interventions therapy. Systematic literature review from available articles and abstracts in PubMed database was summarized in purpose to describe typical presentation and diagnostically challenging features of TDL. One clinical case report presenting tumor-like lesion of the brain, when the diagnosis of TDL was established, is added as an illustrative material.

Key words: multiple sclerosis, neoplasm, tumefactive, demyelination, lesion.

Abbreviations: ADEM- acute demyelinating encephalomyelitis, CNS- central nervous system, CT- computer tomography, FLAIRfluid attenuated inversion recovery, MELAS- mitochondrial encephalopathy, lactic acidosis, and stroke-like episodes, MRI-magnetic resonance imaging, MS-multiple sclerosis, PML- progressive multifocal leukoencephalopathy, TDL-tumefactive demyelinating lesion.

\section{INTRODUCTION}

Demyelinating diseases, such as multiple sclerosis (MS and acute demyelinating encephalomyelitis (ADEM) as well, can simulate brain tumor. Multiple sclerosis (MS) is the most common demyelinating disease of the central nervous system. It is characterized by multifocal demyelinating lesions in the central nervous system (CNS). The diagnosis is often based on clinical picture and confirmed by specific MRI white matter changes disseminated in space and time.

Clinical Picture of MS. MS is the commonest of the demyelinating diseases, caused by the interaction of multiple genetic and environmental factors. It usual affects young adults and onset of the first clinical episode is between 15 and 50 although cases of developing initial symptoms in child or elderly have been reported. Twice as many women as men suffer of MS. Typically clinical course is relapsing remitting in approximately $85 \%$ with usually sub acute, evolving over hours to days, onset and various inter-attack intervals. Patients develop spectrum of symptoms ranging from visual impairment, motor weakness, sensory disturbances, incoordination, cognitive problems, to fatigue and sphincter dysfunction, leading gradually to significant neurological disability. Visual symptoms are among the most common manifestations of demyelinating disease in adults as the initial symptom. An isolated long tract dysfunction as an initial symptom in MS patients is described in $46 \%$, optic neuritis $21 \%$, brainstem dysfunction $9 \%$, combination of symptoms in $24 \%$ with complete recovery from the first episode in $83 \%$ (4). An epilepsy, aphasia, visual fields defects, sudden cognitive deficit were described rarely $(4,11,14)$.

Radiological Picture of MS. The classic radiological appearance of multiple sclerosis is multiple sharply demarcated plaques found in the white matter, typically in the periventricular areas, septocallosal interface, and also in the juxtacortical and infratentorial locations, spinal cord during examination by magnetic resonance (MRI). Contrast enhancement occurs in acute rather than chronic lesions $(5,14)$.

The MRI lesions of ADEM are variable, and range from small to large size, with solid or ring enhancement, and predominantly affecting white but also grey matter. In the majority, the lesions are multifocal and asymmetric in distribution (21).

Histological Picture of MS. MS is the chronic inflammatory demyelinating disease of the central nervous system manifested morphologically by inflammation, demyelination, axonal loss and gliosis. The inflammatory lesions are characterized by massive infiltration by a heterogeneous population of components of the immune system, including $\mathrm{T}$ cells, $\mathrm{B}$ cells, macrophages and microglia, as well as a broad range of cytokines, chemokines, antibodies, complement and other toxic substances. The appearance of such lesions is associated with clinical relapses. Recent detailed immunopathological studies of early, acute lesions revealed profound heterogeneity in the patterns of demyelination and the factors of the immune system involved. During remission, resolution of inflammation is the main factor which leads to clinical improvement of patients $(2,13)$.

Tumefactive Picture of MS. The signs and symptoms related to MS are diverse and white matter abnormalities on MRI are not specific. In a small number of patients with MS brain MRI may be normal and in others it may show diffuse, large or atypical lesions, so as clinical picture is not always classical. A subset of patients with demyelinating disease present with large solitary lesions with prominent edema and mass effect that masquerade as intracranial neoplasm, called demyelinating tumefactive or tumor-like lesion (TDL).

The occurrence of TDL is rare; being estimated at 
1-2/1000 cases of multiple sclerosis, but can cause diagnostic difficulties and also implies further management (8).

Definition of TDL. The tumefactive demyelinating lesions are solitary large (greater than $2 \mathrm{~cm}$ ) lesions with mass-like features and typically showing perilesional edema and/or incomplete ring enhancement in post-gadolinium MR imaging which clinically and radiologically may mimic primary and secondary brain tumor, brain abscess, tuberculous abscess, or other inflammatory disorders $(5,10,16)$.

Clinical Picture of TDL. In the most clinical cases TDL produces clinical symptoms suggestive of a mass lesion. There are some clinical studies characterizing common clinical features of these single episodes in relation to natural course of demyelinating disease with large amount of cases. In most patients with TDLs only single acute clinical attacks have observed, and these generally do not progress to MS. Lucchinetti describes study with 168 patients where presentation of TDL prior to biopsy was a first neurological event in $61 \%$, clinical course was relapsing remitting in $29 \%$ and progressive in $4 \%$.The symptoms of clinical presentation are variable, dependant on lesion location and size, typically polysymptomatic, including headache, cognitive abnormalities, mental confusion, subacute progressive motor and/or sensory hemispheric, and cerebellar syndrome. Also aphasia, apraxia, seizures, visual field defects were observed in some cases. Although aphasia is reported in only $1 \%$ of multiple sclerosis patients Luchinetti reported that $17 \%$ of patients with TDL experienced language disturbances(9).Cognitive dysfunction was a frequent presenting symptom, and included memory dysfunction, mental confusion and disorders of attention in series with more cases analyzed. The seizures as an isolated feature have not been reported, mostly along with hemiparesis or hemianopia. Small number of patients have presented with pediatric or late onset disease $(7,15,17)$.

MR Picture of TDL. Plaques of demyelination of varied size and shape can involve cerebral cortex and subcortical white and grey matter, cerebellar white matter, brain stem and spinal cord. Inflammation, demyelination, and axonal damage characterize MS lesions. Large (2 $\mathrm{cm}$ or more) TDL with mass-like features, although not classical, is a recognized finding in MS. The specificity and accuracy for the diagnosis of TDL were significantly increased by the combined modalities of MR imaging and unenhanced CT versus MR imaging alone with the use of at least one of the MR imaging criteria(6).
These lesions have been described to be generally well demarcated, hypodense on CT and of high T2 signal and relatively low signal on Tl signal on MRI. The lesions are notably found in the white matter. Contrast enhancement, mostly of the rim-enhancement type, is more common in the tumefactive variant than in the standard multiple sclerosis plaque. A helpful diagnostic feature is multiplicity of lesions, often with one of the lesions in a typical periventricular or infratentorial location. The relative lack of mass effect or vasogenic edema given the size of the lesions is also often a clue to the diagnosis. Several case reports and series show decreased perfusion with MR imaging $(5,6,8,10)$.

Less typical radiological presentation of a solitary tumefactive demyelinating lesion mimics a neoplasm, and often necessitates a biopsy.

Pathology of TDL. The histopathological characteristics of demyelinating lesions are the preservation of axons by the presence of neurofilaments, the loss of myelin (negative luxol fast blue staining), presence of macrophages (presence of CD68) and an astrocytic proliferation (presence of glial fibrilary acidic protein) which is characteristic but not specific feature of TDL. It is important to recognize the subtle differences in TDL before sending the material for histopathological investigation so as staining with Luxol fast blue used for confirmation of demyelination is not in routine tumors protocol.

The analysis of 66 patients regarding initial pathological interpretation shows that $19(29 \%)$ were initially misdiagnosed by the referring institution (6 low grade astrocytoma, 2 high grade astrocytoma, 2 lymphoma, 1 vasculitis, 2 progressive multifocal leukoencephalopathy (PML), 1 infarction, l oligodendroglioma, 1 mitochondrial encephalopathy, lactic acidosis, and stroke-like episodes (MELAS), and 3 non-diagnostic) (13).

Combination of MS and Tumor in CNS.

A number of cases have been reported when the coexistence of MS and tumor in the CNS was found, however the incidence of malignant neoplasms in the central nervous system of patients with MS was reported to be less frequent than among the general population (20). 
Table 1. Case summary of literature review

\begin{tabular}{|c|c|c|c|c|c|c|}
\hline & $\begin{array}{l}\text { Author, } \\
\text { Year }\end{array}$ & $\begin{array}{l}\mathrm{N} \text { of } \\
\text { cas- } \\
\text { es }\end{array}$ & Clinical picture & MRI/CT findings & Histhology & Other \\
\hline 1. & $\begin{array}{l}\text { R.S.Bo- } \\
\text { wer et al., } \\
2010^{1}\end{array}$ & 1 & $\begin{array}{l}58 \text { M., } 3 / 52 \text { pro- } \\
\text { gressive apathy, } \\
\text { irritability,confusion }\end{array}$ & $\begin{array}{l}\text { MRI: contrastenhancing, } \\
\text { bifrontal lesion crossing the } \\
\text { corpus callosum, suggestive of } \\
\text { high-grade glioma }\end{array}$ & $\begin{array}{l}\text { Active demyelination. The } \\
\text { large number of foamy } \\
\text { macrophages and scat- } \\
\text { tered reactive astrocytes in } \\
\text { intraoperative smears and } \\
\text { hematoxylin-eosin section. } \\
\text { Luxol fast blue/periodic } \\
\text { acid-Schiff stain demon- } \\
\text { strates myelin loss while } \\
\text { axons are preserved, as } \\
\text { demonstrated by neurofila- } \\
\text { ment stain }\end{array}$ & $\begin{array}{l}\text { Complete re- } \\
\text { covery after } \\
\text { corticoster- } \\
\text { oids }\end{array}$ \\
\hline 2. & $\begin{array}{l}\text { H.M.Tan et } \\
\text { al., } 2004^{19}\end{array}$ & & $\begin{array}{l}30 \text { M., subacute onset } \\
\text { of right-sided weak- } \\
\text { ness and numbness } \\
\text { over } 6 \text { week's duration. } \\
\text { Neurological examina- } \\
\text { tion confirmed a mild } \\
\text { right hemiparesis and } \\
\text { neuropsychological } \\
\text { examination further re- } \\
\text { vealed a clinical tetrad } \\
\text { of right-left disorienta- } \\
\text { tion, finger agnosia, } \\
\text { agraphia and acalculia, } \\
\text { constituting Gerst- } \\
\text { mann's syndrome. }\end{array}$ & $\begin{array}{l}\text { CT scan: hypodense lesion } \\
\text { without significant } \\
\text { enhancement or mass effect } \\
\text { in the superior left parietal } \\
\text { subcortical white matter. MRI: } \\
3 \mathrm{~cm} \\
\text { rounded, well-defined T1 } \\
\text { hypointense, T2 hyperintense } \\
\text { mass with an incomplete rim } \\
\text { of enhancement in the post- } \\
\text { contrast scans. No other similar } \\
\text { mass lesion or focal signal } \\
\text { change. No encroachment into } \\
\text { the grey matter. Accompanying } \\
\text { oedema was disproportionately } \\
\text { mild. Despite its mass-like ap- } \\
\text { pearance, the rim enhancement } \\
\text { and relative little perilesional } \\
\text { oedema were thought to favour } \\
\text { a demyelinating lesion over a } \\
\text { low grade glioma. }\end{array}$ & $\begin{array}{l}\text { Myelin loss associated with } \\
\text { relative preservation of } \\
\text { axons. Immunoperoxidase } \\
\text { for neurofilaments showed } \\
\text { disruption of white matter } \\
\text { tracts with relative pres- } \\
\text { ervation of neurofibrils } \\
\text { whereas Luxol fast blue } \\
\text { stain revealed dissolution } \\
\text { of myelin in the affected } \\
\text { areas. No giant astrocytic } \\
\text { changes or oligodendroglial } \\
\text { inclusions to suggest PML. } \\
\text { Reported to be an astrocyto- } \\
\text { ma on histology. The finally } \\
\text { confirmed a demyelinating } \\
\text { process. }\end{array}$ & \\
\hline 3. & \begin{tabular}{|l|} 
M.E.Evan- \\
gelopou- \\
los et al., \\
$2009^{7}$
\end{tabular} & 1 & \begin{tabular}{|l|}
$23 \mathrm{M} .3 / 52 \mathrm{Hx}$ of \\
blurred vision and \\
instability, lasting for 5 \\
days. Left homonymous \\
hemianopsia. Tendon \\
reflexes equally elicited \\
on both sides for upper \\
and lower limbs and a \\
Babinski sign detected \\
on the left side.
\end{tabular} & $\begin{array}{l}\text { MRI: a large lesion at the right } \\
\text { parietal lobe extending till } \\
\text { the temporal lobe with conse- } \\
\text { quent edema, compressing the } \\
\text { posterior aspect of the right } \\
\text { ventricle. Few small periventri- } \\
\text { calar lesions in both cerebral } \\
\text { hemispheres, cerebellum. No } \\
\text { gadolinium enhancement. No } \\
\text { spinal lesions. }\end{array}$ & & $\begin{array}{l}\text { Received } \\
\text { cortisol IV, } \\
\text { intravenous } \\
\text { methylpred- } \\
\text { nisolone, } \\
\text { neuro- } \\
\text { logical status } \\
\text { gradually } \\
\text { improved. }\end{array}$ \\
\hline 4. & $\begin{array}{l}\text { A.Fallah et } \\
\text { al., } 2010^{8}\end{array}$ & 3 & $\begin{array}{l}50 \mathrm{~F} .3 / 7 \mathrm{Hx} \text { of head- } \\
\text { aches and generalized } \\
\text { tonic-clonic seizures }\end{array}$ & $\begin{array}{l}\text { A computed tomography }(\mathrm{CT}) \\
\text { scan: large right frontal ring } \\
\text { enhancing lesion with central } \\
\text { necrosis, peritumoral edema } \\
\text { and a mild midline shift, most } \\
\text { consistent with a malignant } \\
\text { brain tumour. }\end{array}$ & \begin{tabular}{|l|} 
Postoperative pathology: \\
extensive inflammatory cell \\
reaction, both acute and \\
chronic, with focal necrosis \\
predominantly through the \\
white matter areas. Luxol \\
fast blue staining showed an \\
absence of myelin.
\end{tabular} & \\
\hline
\end{tabular}




\begin{tabular}{|c|c|c|c|c|c|c|}
\hline & & & \begin{tabular}{|l|}
43 F., $4 / 7$ Hx of left \\
facial droop and left \\
arm weakness, more \\
pronounced distally. \\
Physical examination \\
confirmed these symp- \\
toms, including gait \\
ataxia. Medical history \\
included a diagnosis of \\
MS 3 years ago when \\
had transverse myelitis.
\end{tabular} & $\begin{array}{l}\text { MR obtained } 3 \text { years earlier } \\
\text { showed transverse myelitis } \\
\text { from T4 to T7 with unremark- } \\
\text { able intracranial pathology. A } \\
\text { new CT scan of head showed } \\
\text { a large solitary right frontal hy- } \\
\text { podense white-matter lesion. It } \\
\text { was unclear whether this repre- } \\
\text { sented a tumefactive multiple } \\
\text { sclerotic lesion or a low-grade } \\
\text { cystic neoplasm. }\end{array}$ & $\begin{array}{l}\text { The diagnosis of MS was } \\
\text { confirmed }\end{array}$ & \\
\hline & & & $\begin{array}{l}35 \text { F. New-onset gen- } \\
\text { eralized tonic-clonic } \\
\text { seizures and headaches }\end{array}$ & $\begin{array}{l}\text { MRI: a large right frontal mass } \\
\text { with surrounding edema and a } \\
\text { mild midline shift }\end{array}$ & $\begin{array}{l}\text { Lowgrade glioma and reac- } \\
\text { tive gliosis were among the } \\
\text { likely differential diagnoses. } \\
\text { Permanent section showed } \\
\text { a } \\
\text { demyelinating lesion. }\end{array}$ & \\
\hline \multirow[t]{3}{*}{5.} & $\begin{array}{l}\text { M.Van } \\
\text { Lan- } \\
\text { digham et } \\
\text { al, } 2010^{21}\end{array}$ & 3 & $\begin{array}{l}\text { Child. 3/52 Hx of ataxia } \\
\text { and diplopia }\end{array}$ & $\begin{array}{l}\text { MRI:asymmetric T2/fluid-at- } \\
\text { tenuated inversion recovery } \\
\text { hyperintensity within the pons }\end{array}$ & & $\begin{array}{l}\text { Improved } \\
\text { with cor- } \\
\text { ticosteroid } \\
\text { therapy }\end{array}$ \\
\hline & & & $\begin{array}{l}\text { Child. Sudden onset of } \\
\text { coma. Elevated ICP }\end{array}$ & $\begin{array}{l}\text { A large heterogenously enhanc- } \\
\text { ing temporal lobe mass, with } \\
\text { extensive edema }\end{array}$ & $\begin{array}{l}\text { cortical biopsies revealed } \\
\text { ADEM }\end{array}$ & $\begin{array}{l}\text { Improved } \\
\text { with cor- } \\
\text { ticosteroid } \\
\text { therapy }\end{array}$ \\
\hline & & & $\begin{array}{l}\text { Child. } 4 / 12 \mathrm{Hx} \text { of } \\
\text { increasing lethargy } \\
\text { and clumsiness in all } \\
\text { extremities }\end{array}$ & $\begin{array}{l}\text { Multiple small brain lesions } \\
\text { with occasional ring enhance- } \\
\text { ment }\end{array}$ & $\begin{array}{l}\text { cortical biopsies revealed } \\
\text { ADEM }\end{array}$ & $\begin{array}{l}\text { Improved } \\
\text { with cor- } \\
\text { ticosteroid } \\
\text { therapy } \\
\end{array}$ \\
\hline 6. & $\begin{array}{l}\text { MK Sinha, } \\
2010^{17}\end{array}$ & 2 & $\begin{array}{l}23 \text { F. Recurrent right } \\
\text { focal tonic-clonic } \\
\text { seizures with second- } \\
\text { ary generalization of } \\
\text { three-month duration. } \\
\text { Normal neurological } \\
\text { examination }\end{array}$ & \begin{tabular}{|l|} 
A rounded well-defined \\
lobulated T1 hypointense \\
mass measuring about $5 \mathrm{~cm}$ \\
in left fronto-parietal region, \\
which was hyperintense in T2- \\
weighted and fluid-attenuated \\
inversion recovery (FLAIR) \\
images, with a mild incomplete \\
rim of enhancement in the \\
post-contrast scans. Reported to \\
be an astrocytoma elsewhere. \\
Repeat neuroimaging demon- \\
strated an increase in the mass \\
effect and edema. No encroach- \\
ment into the adjacent grey \\
matter. Though the mass was \\
large in size, the surrounding \\
edema and mass effect were \\
disproportionately mild
\end{tabular} & & $\begin{array}{l}\text { Rapic clinical } \\
\text { improve- } \\
\text { ment after } \\
\text { intravenous } \\
\text { methylpred- } \\
\text { nisolone }\end{array}$ \\
\hline
\end{tabular}




\begin{tabular}{|c|c|c|c|c|c|}
\hline & & $\begin{array}{l}48 \mathrm{M} \text {. Right homony- } \\
\text { mous hemianopia } 1 / 12, \\
\text { difficulties reading }\end{array}$ & $\begin{array}{l}\text { An irregular well-defined mass } \\
\text { measuring } 4.8 \mathrm{~cm} \text { in the left pa- } \\
\text { rieto-temporal region involving } \\
\text { splenium of corpus callosum } \\
\text { with mass effect on adjacent } \\
\text { structures. The lesion was hy- } \\
\text { perintense on T2-weighted and } \\
\text { FLAIR images with incomplete } \\
\text { rim of enhancement in the } \\
\text { post-contrast images. Initially, a } \\
\text { diagnosis- brain tumor }\end{array}$ & $\begin{array}{l}\text { Perivascular lymphocytic } \\
\text { infiltrate and aggregates of } \\
\text { foam cells in white matter } \\
\text { with relatively uninvolved } \\
\text { grey matter, suggestive of } \\
\text { tumefactive demyelinating } \\
\text { lesion }\end{array}$ & $\begin{array}{l}\text { Rapic clinical } \\
\text { improve- } \\
\text { ment after } \\
\text { intravenous } \\
\text { methylpred- } \\
\text { nisolone }\end{array}$ \\
\hline 7. & $\begin{array}{l}\text { V.Puri et } \\
\text { al., } 2004^{15}\end{array}$ & $\begin{array}{l}13 \text { F. Episodes of hemi- } \\
\text { plegia and hemianopia } \\
\text { involving opposite } \\
\text { sides, each time associ- } \\
\text { ated with seizures. }\end{array}$ & $\begin{array}{l}\text { MR: a giant demyelinating, } \\
\text { peripherally enhancing lesion } \\
\text { with mass effect. MR spectros- } \\
\text { copy (MRS) was indistinguish- } \\
\text { able from a tumor }\end{array}$ & $\begin{array}{l}\text { Histopathology revealed an } \\
\text { acute demyelinating lesion } \\
\text { with no evidence of tumor }\end{array}$ & $\begin{array}{l}\text { Partial clini- } \\
\text { cal recovery } \\
\text { after corti- } \\
\text { costeroids }\end{array}$ \\
\hline 8. & $\begin{array}{l}\text { S.Yama- } \\
\text { shita et al. } \\
2006^{22}\end{array}$ & $\begin{array}{l}27 \mathrm{~F} \text {. Clumsiness of } \\
\text { right hand followed } \\
\text { by progressive right } \\
\text { hemiparesis within } \\
\text { several days. Physical } \\
\text { examination:severe } \\
\text { weakness and hyper- } \\
\text { reflexia in the right up- } \\
\text { per and lower extremi- } \\
\text { ties }\end{array}$ & $\begin{array}{l}\text { MR: a large ring-enhancing } \\
\text { lesion with surrounding edema } \\
\text { and mass effect in the left fron- } \\
\text { tal lobe }\end{array}$ & $\begin{array}{l}\text { A macrophage-rich le- } \\
\text { sion with gliosis of reactive } \\
\text { astrocytes. Klüver-Barrera } \\
\text { stain: total myelin loss. Bo- } \\
\text { dian stain: relative axonal } \\
\text { preservation, consistent } \\
\text { with demyelinating disease. } \\
\text { No evidence of cell neopla- } \\
\text { sia. }\end{array}$ & $\begin{array}{l}\text { Recovery } \\
\text { after corti- } \\
\text { costeroids }\end{array}$ \\
\hline 9. & $\begin{array}{l}\text { S.Navarro } \\
\text { et al, } \\
2005^{12}\end{array}$ & $\begin{array}{l}31 \mathrm{~F} .48 / 24 \mathrm{Hx} \text { of a } \\
\text { progressive aphasia } \\
\text { and a sensory parietal } \\
\text { syndrome }\end{array}$ & $\begin{array}{l}\text { A hyperintense in T2 lesion } 3.6 \\
\text { cm in diameter with perile- } \\
\text { sional edema and minimal } \\
\text { gadolinium uptake, along with } \\
\text { other images that revealed } \\
\text { increased signal intensity in } \\
\text { the periventricular subcortical } \\
\text { white matter on the right-hand } \\
\text { side and in the left-hand fron- } \\
\text { tal subcortical region. Was not } \\
\text { possible to distinguish between } \\
\text { a demyelinating disease and a } \\
\text { high grade glioma. }\end{array}$ & $\begin{array}{l}\text { demyelinating pseudotu- } \\
\text { moral lesion }\end{array}$ & \\
\hline 10. & $\begin{array}{l}\text { T.Take- } \\
\text { uchi et al., } \\
2008^{18}\end{array}$ & $\begin{array}{l}87 \text { F. } 2 / 52 \text { Hx of right- } \\
\text { sided progressive hemi- } \\
\text { paresis, slurred speech. } \\
\text { Previous Hx of uterine } \\
\text { cancer } 35 \text { yrs ago. }\end{array}$ & $\begin{array}{l}\text { Tumor-like lesion with little } \\
\text { mass effect and edema }\end{array}$ & & \\
\hline 11. & $\begin{array}{l}\text { MA.Tari- } \\
\text { cco et al., } \\
2002^{20}\end{array}$ & $\begin{array}{l}31 \mathrm{M} \text {. Rapid onset of } \\
\text { right side weakness and } \\
\text { loss of vision. A diag- } \\
\text { nosis of MS confirmed } \\
\text { by CSF analysis and } \\
\text { MRI. Nine years later } \\
\text { developed progressive } \\
\text { tetraparesis, leading } \\
\text { initially to suspicion } \\
\text { of illness relapse and a } \\
\text { demyelinating plaque } \\
\text { in the spinal cord }\end{array}$ & $\begin{array}{l}\text { MR: a large spinal cord lesion } \\
\text { with isointense signal on T1 } \\
\text { weighed MR between the } \\
\text { second and seventh cervical } \\
\text { vertebrae, with a cystic nodule } \\
\text { at the C3 level. Brain MR: T2 } \\
\text { weighed MR exhibited small } \\
\text { lesions suggestive of demyelini- } \\
\text { zation plaques }\end{array}$ & Revealed an ependimoma & \\
\hline
\end{tabular}


Case report as an illustrative example from Latvian MS data base:

28 years old female presented with acute onset and progressive right sided leg weakness and pain. In 2/52 period lower paraparesis and urine frequency developed. MR imaging scans showed large rounded T2 and FLAIR hyperintense tumor-like lesion in the left frontal lobe with incomplete ring enhancement and mild perifocal edema, and one small enhancing periventricular lesion (Fig.1). Nonenhancing hyperintense lesions in both optic nerves and two T2 hyperintense enhancing lesions with edema in the cervical and thoracic spinal cord were found as well.

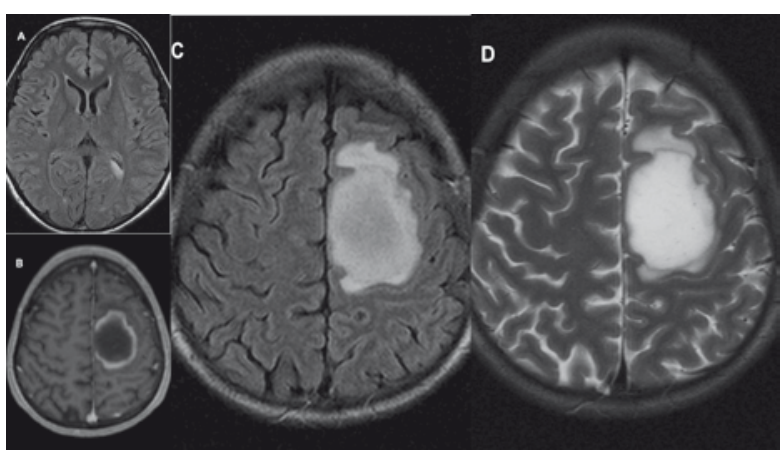

Fig. 1. Representative samples of TDL in MR imaging: A.FLAIR axial, B.T1-weighted axial post contrast, C.FLAIR axial, D.T2-weighted axial

The most likely working diagnosis was neoplasm. Patient underwent stereotactic surgery and histology results from brain biopsy reported features typically to demyelination. Patient was sent for further investigations to MS centre. Detailed retrospective clinical history clarified previous optic neuritis. No other relevant symptoms related to possible demyelinating disease were found. Diagnosis of MS was established. The full clinical recovery after intravenous prednisolone course was observed.

\section{CONCLUSIONS}

There is a high importance of obtaining a detailed neurological history in all adult patients with presenting tumor-like lesions. The particular attention to prior episodes of transient neurological dysfunction for which the patient may not have sought medical attention may be very helpful specifying features more characteristic to demyelinating disease.

In some cases when a brain biopsy may be necessary, it is important for clinician to have a consideration of a demyelinating lesion so as standard tumor histopathological protocols do not include staining with Luxol fast blue used for detecting myelination.

However, a pre-existing diagnosis of multiple sclerosis does not exclude the possibility of a coexisting tumor, or other additional pathology.
Conflict of interest: None

\section{REFERENCES}

1. Bower RS, Burrus TM, Giannini C, Erickson BJ, Meyer FB, Pirko I, Mauermann ML. Teaching NeuroImages: Demyelinating disease mimicking butterfly high-grade glioma // J Neurol, 2010;75: e4-e5

2. Brück W. The pathology of multiple sclerosis is the result of focal inflammatory demyelination with axonal damage.// J Neurol, 2005;252(5)V/3-V/9

3. Caroli E, Salvati M, Ferrante L. Tumor-like multiple sclerosis: report of four cases and literature review // Tumori,2006;92(6):559-62

4. Confavreux C, Vukusic S. Natural history of multiple sclerosis: a unifying concept //J Neurol Neurosurg Psychiatry, 2005;76:1693-1697

5. Curtis A, Given B, Scott S, Lee C. The MRI Appearance of Tumefactive Demyelinating Lesions / / AJR, 2004; 182:195-199

6. Kim DS, Na DG, Kim KH, Kim J, Kim E, Yun BL, Chang KH. Distinguishing Tumefactive Demyelinating Lesions from Glioma or Central Nervous System Lymphoma: Added Value of Unenhanced CT Compared with Conventional Contrast-enhanced MR Imagingl // Radiology, 2009; 251:467-475

7. Eleptheria EM, Evangelopoulos DS, Potagas C, Sfagos C. Homonymous hemianopsia as the leading symptom of a tumor like demyelinating lesion: a case report // Cases Journal, 2009; 2:9366

8. Aria F, Banglawala S, Ebrahim S, Paulseth JE, Jha NK. Tumefactive demyelinating lesions: a diagnostic challenge // Can J Surg, 2010;53(1):69-70

9. Lucchinetti CF, Gavrilova RH, Metz I, Parisi JE, Scheithauer BW, Weigand S, K. Thomsen K, Mandrekar J, Altintas A, Erickson BJ, Konig F, Giannini C, Lassmann H, Linbo L, Pittock SJ, Bruck W. Clinical and radiographic spectrum of pathologically confirmed tumefactive multiple sclerosis //Brain, 2008;131:1759-75

10. Malhotra HS, Jain KK, Agarwal A, Singh MK, Yadav SK, Husain M. Characterization of tumefactive demyelinating lesions using MR imaging and in-vivo proton MR spectroscopy //Mult Scler, 2009; 15:193-203

11. Koch M, Uyttenboogaart M, Polman S, Keyser JD. Seizures in multiple sclerosi .//Epilepsia, 2008;49(6):948-953

12. Navarro $S$, Mondéjar-Marín B, Pedrosa-Guerrero A, Pérez-Molina I, Garrido-Robres JA, AlvarezTejerina A. Aphasia and parietal syndrome as the presenting symptoms of a demyelinating disease with pseudotumoral lesions // Rev Neurol., 2005;16-30;41(10):601-3 
13. Pittock SJ, McClelland RL, Achenbach SJ, Konig F, Bitsch A, BruØck W, Lassmann H, Parisi JE, Scheithauer BW, Rodriguez M, Weinshenker BG, Lucchinetti CH. Clinical course, pathological correlations, and outcome of biopsy proved inflammatory demyelinating disease // Brain, 2006; 129:606-616

14. Poser S, Luer W, Bruhn H, Frahm J, Bruck Y, Felgenhauer $K$. Acute demyelinating disease. Classification and non-invasive diagnosis // Acta Neurol Scand, 1992; 86: 579 - 85

15. Puri V, Chaudhry N, Gulati P, Tatke M, Singh D. Recurrent tumefactive demyelination in a child // J Clin Neurosci, 2005; 12:495-500

16. Saindane AM, Cha S, Law M, Xue X, Knopp EA, and Zagzag D. Proton MR Spectroscopy of Tumefactive Demyelinating Lesions // AJNR Am J Neuroradiol, 2002; 23:1378 - 1386

17. Sinha MK, Garg RK, Bhatt M, Chandra A. Tumefactive demyelinating lesion: Experience with two unusual patients // J Postgrad Med, 2010; 56:146-9

18. Takeuchi T, Ogura M, Sato M, Kawai N, Tanihata $\mathrm{H}$, Takasaka I, Minamiguchi H, Nakai M, Itakura T. Late-onset tumefactive multiple sclerosis // Radiat Med., 2008; 26(9):549 - 52
19. Tan HM, Chan L, Chuan L, Goh NSS, Tang KK Case report. Monophasic, solitary tumefactive demyelinating lesion: neuroimaging features and neuropathological diagnosis // The British Journal of Radiology, 2004; (77), 153 - 156

20. Augusto TM, Machado A, Callegaro D, Marino R. Spinal cord tumor in a patient with multiple sclerosis // Arq Neuropsiquiatr, 2002; 60(2-B): $475-477$

21. VanLandingham M, Hanigan W, Vedanarayanan V, Fratkin J. An uncommon illness with a rare presentation: neurosurgical management of ADEM with tumefactive demyelination in children // Childs Nerv Syst., 2010; 26(5):655 - 61

22. Satoshi $Y$, Kimura E, Hirano $T$, Uchino $M$. Tumefactive Multiple Sclerosis // Inter Med, 2009; 48:1113-1114

\section{Address:}

Liene Elsone

MS centre

Vecmilgravis 5 line 26,

Riga, Latvia, LV-1015

E-mail; Liene.elsone@gmail.com 